\title{
An Improved Measurement Accuracy of Fetal Heart Rate using Digital Filter
}

\author{
Riska Setyawati ${ }^{1}$, Priyambada Cahya Nugraha ${ }^{1}$, Her Gumiwang Ariswati ${ }^{1}$, Nur Hasanah Ahniar $^{2}$ \\ ${ }^{1}$ Department of Medical Electronics Engineering Technology, Poltekkes Kemenkes Surabaya \\ Jl. Pucang Jajar Timur No. 10, Surabaya, 60282, Indonesia \\ ${ }^{2}$ Department of Medical Electronics Engineering Technology, Poltekkes Kemenkes Jakarta II Jakarta \\ Jl. Hang Jebat III/F3, Kebayoran Baru, South Jakarta, 12120,Indonesia
}

riskasetyaw@gmail.com,pcn1967@poltekkesdepkes-sby.ac.id, ariswatihergumiwang@gmail.com.

\begin{tabular}{|c|c|}
\hline Article Info & bstract \\
\hline $\begin{array}{l}\text { Article History: } \\
\text { Received May 15, } 2020 \\
\text { Revised Nov 14, } 2020 \\
\text { Accepted Nov 25, } 2020\end{array}$ & $\begin{array}{l}\text { In the non-stress test, there are several parameters including the fetal Doppler. fetal doppler is used } \\
\text { to detect the fetal heart in the womb. It can be seen that the fetal heart rate in the womb under normal } \\
\text { circumstances is in the range of } 120-140 \text { beats per minute. Noise on doppler fetal output can affect fetal } \\
\text { heart rate readings. the purpose of this research is to design a non-stress test device that is displayed on } \\
\text { nextion. The contribution of this research is the creation of a portable device with a nextion display and } \\
\text { using analog and digital filters that can be used as noise removal. the method used to eliminate noise by }\end{array}$ \\
\hline $\begin{array}{l}\text { Keywords: } \\
\text { Non-stress test; Fetal } \\
\text { doppler ; piezoelectric } \\
\text { sensor; analog filter; } \\
\text { digital filter; Arduino; } \\
\text { TFT LCD }\end{array}$ & $\begin{array}{l}\text { using a bandpass type filter design frequency } 20-40 \mathrm{~Hz} \text { by designing a large frequency suppression } \\
\text { outside the cutoff so that noise is not counted as a fetal heart rate. to detect the fetal heart rate in the } \\
\text { mother's womb using a piezoelectric sensor. then the fetal heart rate obtained is filtered and the data is } \\
\text { processed using Arduino after the results of processing the filter between analog bandpass and digital } \\
\text { bandpass type Chebyshev method I then the results of the tool will be displayed on nextion. The results } \\
\text { showed that measurements on analog filter modules that have been made produce an error value of } \\
8.62 \% \text { and digital filters that have been made produce an error value of } 12.97 \% \text {. The results of this } \\
\text { study can be applied to fetal heart rate gauges portable at a health clinic. }\end{array}$ \\
\hline
\end{tabular}

\section{Corresponding Author:}

Priyambada Cahya Nugraha

Department of Medical Electronics Engineering Technology

Politeknik Kesehatan Kementerian Kesehatan Surabaya

Jl. Pucang Jajar Timur No. 10, Surabaya (60282), Indonesia

E-mail: pcn1967@poltekkesdepkes-sby.ac.id
This work is an open-access article and licensed under a Creative Commons Attribution-ShareAlike 4.0 International License (CC BY-SA 4.0).

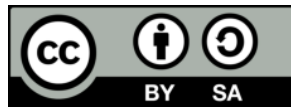

\section{INTRODUCTION}

A total of 7,000 newborns in the world die every day (Indonesia: 185 / day, with AKN 15/1000 Survival) [1]. Threequarters of neonatal deaths occur in the first week, and $40 \%$ die within the first 24 hours [2]. Neonatal death can be prevented by the adequacy of fetal oxygenation to avoid hypoxia. If hypoxia occurs, there may be a decrease in fetal brain blood flow. Therefore, monitoring the fetal heart rate can recognize fetal asphyxia[3]. Not a few fetal asphyxia occurs, fetal asphyxia is severe enough to cause neurological damage or even fetal death[4]. Neonatal mortality is closely related to the quality of labor, and the delay in diagnosis of the fetus [5]. Non Stress Test can be an alternative to reduce infant mortality [6]. The nonstress test has three parameters namely the parameters of the fetal heart rate, uterine contractions, and a marker button when there is movement from the fetus[7]. This test is performed while the patient is lying down. A belt with sensors that measure the heart rate of the fetus is placed around the patient's stomach Fetal heart rate parameters are used to detect a fetal heartbeat in the mother's womb[8]. Fetal heart rate is a very important parameter that can be monitored which acts as an indicator to determine fetal well-being[9]. Normal and abnormal fetuses can be characterized by a heartbeat [10]. Fetal heart rate can determine fetal development and the presence or absence of congenital heart disease[11]. The range of secure baseline fetal heart rate is $110 \mathrm{bpm}$ to $160 \mathrm{bpm}$. The baseline fetal heart rate higher than $160 \mathrm{bpm}$ is called tachycardia and less than $110 \mathrm{bpm}$ is called bradycardia[12]. Noise often can affect the reading of the fetal heart rate.

Several studies have been conducted to detect fetal heart rates, one of which is research on Home Based Fetal Heart Rate 
Monitor, There are several shortcomings in the study, namely using a condenser microphone. the sensor used is considered less sensitive in reading the sound of the fetal heart rate[13]. Then there is the development of research with a different sensor that is Design of Detector and Heart Rate Counters with the principle of Doppler in this study using ultrasound sensors, where there are weaknesses in this tool that the sensor is considered too sensitive to vibration[14]. With ultrasound frequencies in the typical range of $1 \mathrm{MHz}-3 \mathrm{MHz}$ [15]. The next search is Portable Doppler Equipped with Two Measurement Methods, this study also uses a piezoelectric ultrasound sensor to capture the fetal heart rate, in this study using an analog filter circuit with IC TL064. According to researchers, there are still shortcomings, especially in the filter[16]. The next search is the Mini Doppler Detector Circuit Design, in this study only focuses on the expected output that can detect frequencies of 2 to $3 \mathrm{~Hz}$ but there is a weakness that has not been realized in a mini doppler hardware detector[17]. The next search is the research on "Designing digital filters on fetal doppler" digital filters here use the Chebyshev type bandpass filter method with a frequency of $2-3 \mathrm{~Hz}$. This study only focused on filter design and some disadvantages are still using a computer as a signal processing[18]. The next search is Implementation and Analysis of Fetal Doppler to Detect Fetal Heartbeat with Digital Signal Processing. In this study, it was explained that the researchers did not design the filter but the researchers used a fetal mainboard that was already in the form of a kit with the information of $115 \mathrm{~Hz}$ highpass frequency and $750 \mathrm{~Hz}$ lowpass frequency. there are weaknesses in this study, namely, it is not known in more detail about the filter, and still using the Delphi application as a graphical display on a PC [19]. The next search is a fetal heart rate measurement application based on ultrasonic fetal monitor Doppler, this tool uses a piezoelectric Doppler ultrasonic sensor using a digital FIR filter and 9-39 Hz PassBand Frequency signal processing, in this study the researchers assessed that the results obtained were not too far from the instrument, By comparison, the researcher also suggested further development using the IIR method. There is a weakness in this research that is still using a computer so that the results of the inspection cannot be seen at the time [20]. The next search is Non-Stress Test Shown PC. This tool not only displays the value of the fetal heart rate but there are three parameters namely, fetal heart rate, uterine contractions, and buttons to indicate fetal movement. This tool only uses LPF analog filters and no mention of the cutoff frequency value is used. There is also a tool that still uses the ATMega8 microcontroller as a data processor, and this tool requires $\mathrm{PL}$ 2303 to interface to a PC [21].

Based on the discussion above there are some weaknesses regarding the process, from most previous studies using computers, and the absence of a monitor device that is used portable, so the writer will make a Non-Stress Test tool displayed on TFT LCD, with three parameters namely, fetal heart rate, uterine contractions, and a button marking fetal movement. In this study, the authors used a piezoelectric sensor[22] and the author wanted to find out the fetal heart rate signal using a digital filter IIR[23] Chebysev method and an analog filter using a cutoff frequency of $20 \mathrm{~Hz}-40 \mathrm{~Hz}$ following the frequency of the fetal heart rate[24]. In this study, the author will use the Arduino module[25] as a data processor and output on the TFT LCD[26], by displaying a graph of fetal heart rate and BPM values. Accu is used as a power supplier (portable), so it is hoped that this tool can make it easier if it is done a direct checkup.

This Article is composed of: Chapter 1 introduction, Chapter 2 Material and Methods, Chapter 3 Result, Chapter 4 Discussion, Chapter 5 Conclusion, and Chapter 6 Reference.

\section{MATERIALS AND METHODS}

\section{A. Experimental Setup}

This study used one subject randomly drawn. Bpm value data is collected by placing the sensor on the HEART. Data collection is done ONE time. Analog filter testing is done by using the function and oscilloscope to find out whether the cutoff frequency is appropriate ie $20-40 \mathrm{~Hz}$. Testing of the digital filter is done by simulating a Matlab application.

\section{B. Materials and Device}

This study uses a $2 \mathrm{MHz}$ piezoelectric sensor to measure the fetal heart rate. make amplifier circuit using Ic LM 358, make analog filter circuit frequency $20-40 \mathrm{~Hz}$, set digital filter program with Matlab R2008b. Atmega 2560-16AU IC microcontroller is used to process the system. Nextion 5-inch TFT LCD for displaying graphics and FHR and UC values. Use the battery as a power supply (Panasonic).

\section{Experiment}

In this study, researchers measured fetal heart rate values, respondents were randomly selected and the results were compared with average calculations.

\section{The Diagram Block}

Input is obtained from fetal heartbeat signals. The Doppler parameter uses a piezoelectric sensor to knock the fetal heartbeat signal. On this sensor, there is a piezoelectric that is given a negative pole or ground tip and the result is that there are three output legs namely the result of a series ground, a positive left side piezo, and a positive right side pole, which will enter the oscillator input, and two positive poles enter the oscillator receiver and transmitter. After that the poles that get the oscillator transmitter are generated with a frequency of $2 \mathrm{MHz}$ and the poles that receive the receiver carry a frequency range of $10-40 \mathrm{~Hz}$ depending on the hardness of the heart captured by a high amplitude piezoelectric sensor which is still in the $\mathrm{mV}$ unit, the oscillator module also has an amplifier then the amplitude which was originally still in $\mathrm{mV}$ to a volt range that is between 3-4Volt depending on the hardness of the heart. Fetal heart signal captured by piezoelectric will be separated from the carrier signal by a demodulator circuit, henceforth the fetal heart rate signal is strengthened again before it is filtered using an analog bandpass filter $20-40 \mathrm{~Hz}$ cutoff frequency and at the same time filtering with 
a digital filter bandpass filter Chebyshev type I with frequency cutoff $20-40 \mathrm{~Hz}$, the results will be processed by Arduino and displayed in the form of a heart signal and fetal heart rate bpm onvoltage of $0-5 \mathrm{~V}$. the TFT LCD. (Fig. 1).

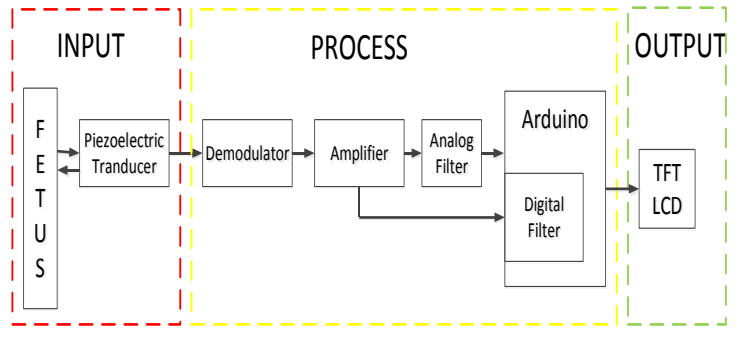

Fig 1. The diagram block of the Non Stress Test with TFT LCD Display

\section{E. The Flowchart}

in the current process flow chart begins at the initialization series will advance after that there will be selection mode filter is a digital filter mode and analog filter mode, after the filter has been select the automatic mode will do reading fetal heart rate. The results of the fetal heart rate detection readings will then be displayed on the TFT LCD. (Fig. 2).

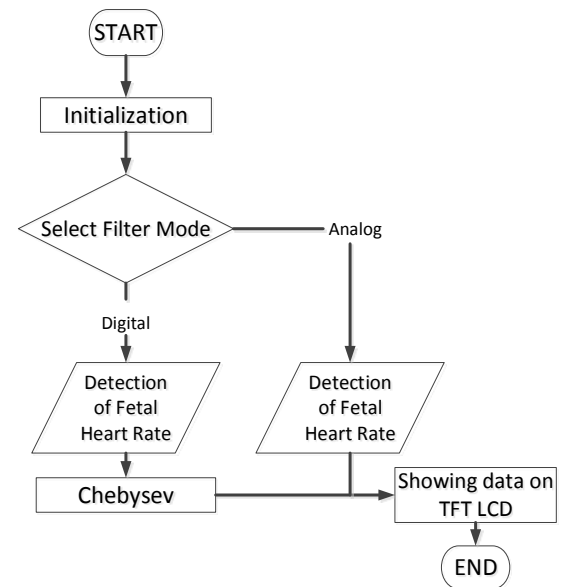

Fig 2. The Flowchart of the of the Non Stress Test with TFT LCD Display

\section{F. Circuit}

\section{1) Inverting amplifier}

In (Fig. 3.), an inverting amplifier is used to reverse the sine signal from a piezoelectric output with an output voltage of $2.3 \mathrm{~V}$ $2.8 \mathrm{~V}$

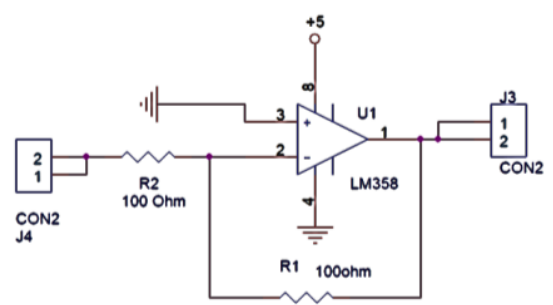

Fig 3. Inverting amplifier to reverse the sine signal

\section{2) Comparator}

In (Fig. 4 ), comparators are used to form a box signal with a

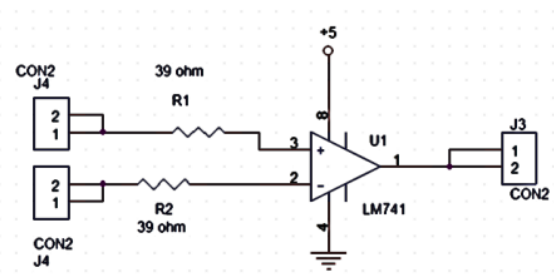

Fig 4. Comparator to compare the input voltage

3) Difference amplifier

In (Fig. 5 ), Difference amplifier are used to form a sine signal with an output of $0-2,8 \mathrm{~V}$

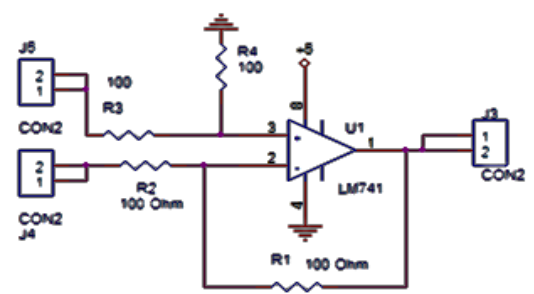

Fig 5. Difference amplifier to compare form a sine signal

4) Demodulator

In (Fig. 6 ), a Demodulator is used to form an audio signal

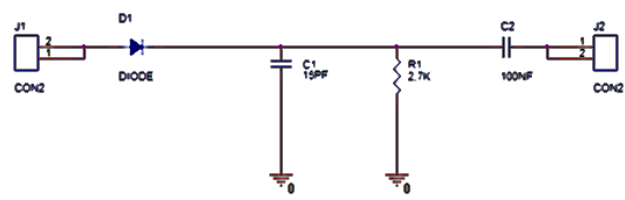

Fig 6. The demodulator is used to form an audio signal

\section{5) Lowpass filter frequency cutoff $100 \mathrm{~Hz}$}

In (Fig. 7 ), a lowpass filter is used as an initial filter so that the BPF filter has no noise from the $2 \mathrm{MHz}$ frequency.

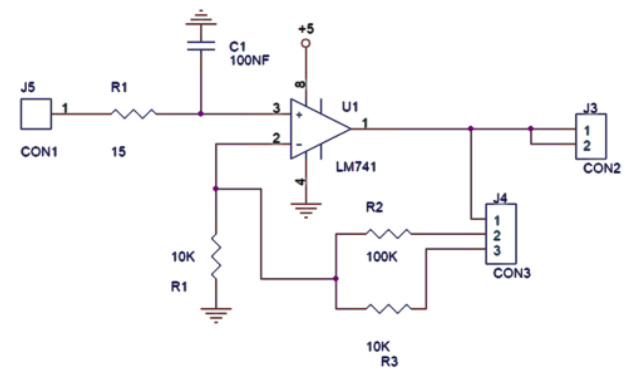

Fig 7. LowpassFilter are used to eliminate frequencies above $100 \mathrm{~Hz}$ 
6) Bandpass filter frequency cutoff $20-40 \mathrm{~Hz}$

In (Fig. 8 ), BandpassFilter is used to get a cutoff frequency of $20-40 \mathrm{~Hz}$ which is the frequency of the fetal heart rate

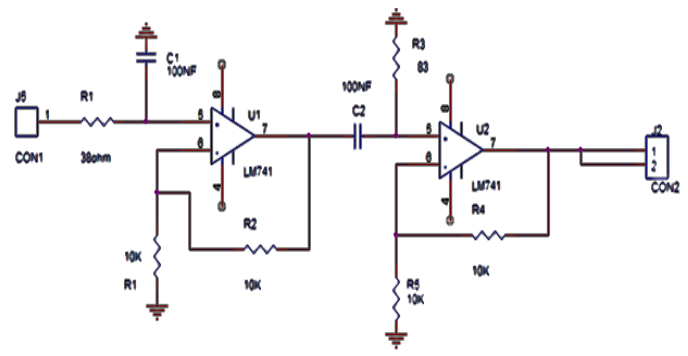

Fig 8. Bandpass Filter is used to getting a cutoff frequency of 20$40 \mathrm{~Hz}$

\section{RESULTS}

A. Result of filter analog (bandpass filter 20-40Hz)

In (Fig. 9), the researcher examines the cutoff value of an analog filter using a function and oscilloscope, and the test results prove that the filter used by a predetermined cutoff frequency is 20 $40 \mathrm{~Hz}$.

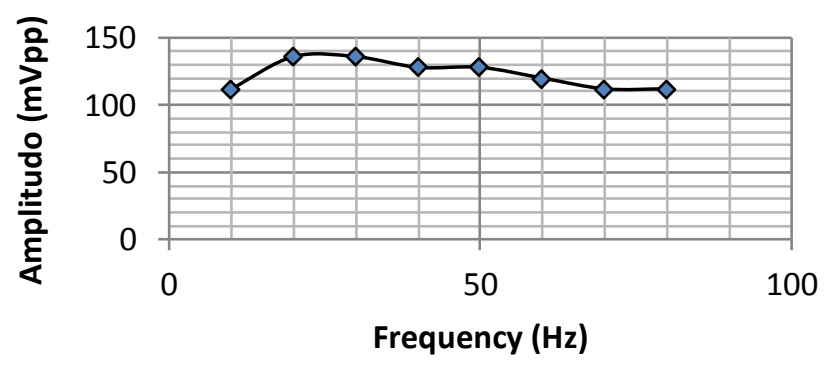

Fig 9. Result of filter analog frequency cut off $20-40 \mathrm{~Hz}$

\section{B. Result of filter digital}

The FFT also shows that the $10 \mathrm{~Hz}, 30 \mathrm{~Hz}$ and $50 \mathrm{~Hz}$ frequencies before filtering in Fig. 10 will experience amplitude suppression at the $10 \mathrm{~Hz}$ and $50 \mathrm{~Hz}$ frequencies because these frequencies are not cutoff frequencies while the $30 \mathrm{~Hz}$ frequencies do not experience an emphasis on amplitude because the $30 \mathrm{hz}$ frequency is between the cutoff frequency. seen in Fig. 11

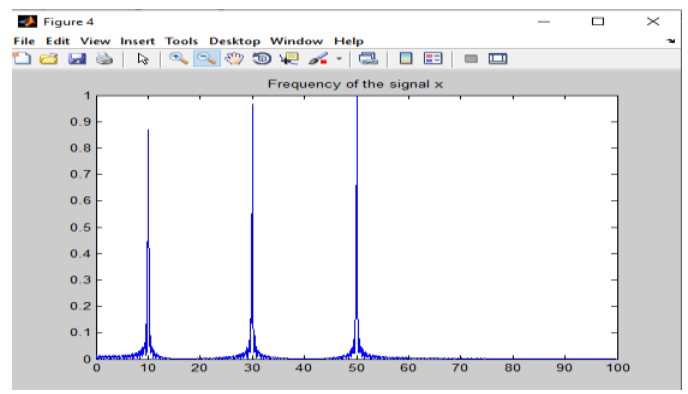

Fig 10.

FFT Signal before filtering using Matlab

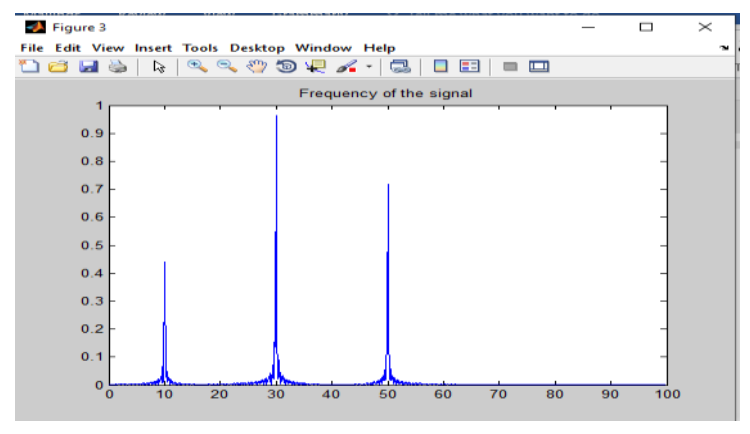

Fig 11. FFT Signal After filtering using Matlab

\section{Result of Respondent}

In (Fig. 12), the researcher measures the heart rate (BPM) results from digital filters and analog filters on the TFT LCD, respondents are randomly selected and the results are compared with BPM on the pulse oximetry device.

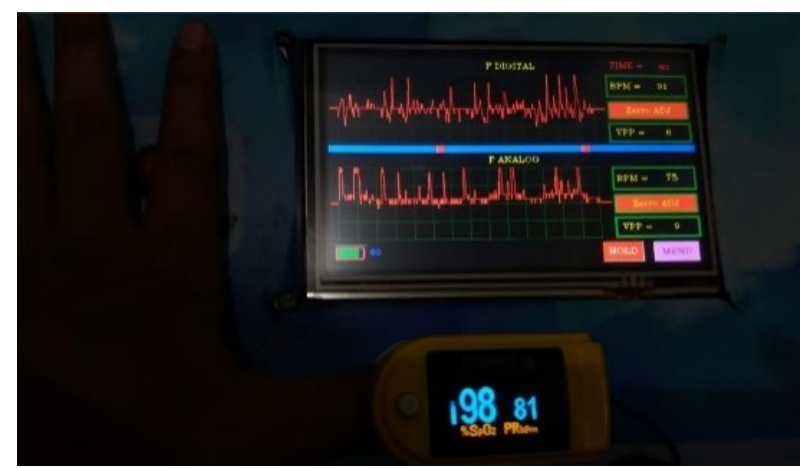

Fig 12. Results of Respondent to Be Compared With Standard (Pulse Oximetry Elitech)

\section{Listing program void setup}

The program functions as a declaration of each $\mathrm{tft}$ nextion page to display the results.

void setup ()\{

Seriall.begin(9600);

delay (50);

Serial1.print("baud=115200");

Serial1.write(0xff);

Serial1.write(0xff);

Serial1.write(0xff);

Seriall.end();

Seriall.begin(115200);

Serial.begin(115200);

page0.attachPush(page0PushCallback); page1.attachPush(page1PushCallback); page2.attachPush(page2PushCallback); page3.attachPush(page3PushCallback); page4.attachPush(page4PushCallback); page5.attachPush(page5PushCallback); page6.attachPush(page6PushCallback); 


\section{E. Listing program void loop}

The program functions as a battery indicator on the device and reads values on analog pins for analog filters and digital filters.

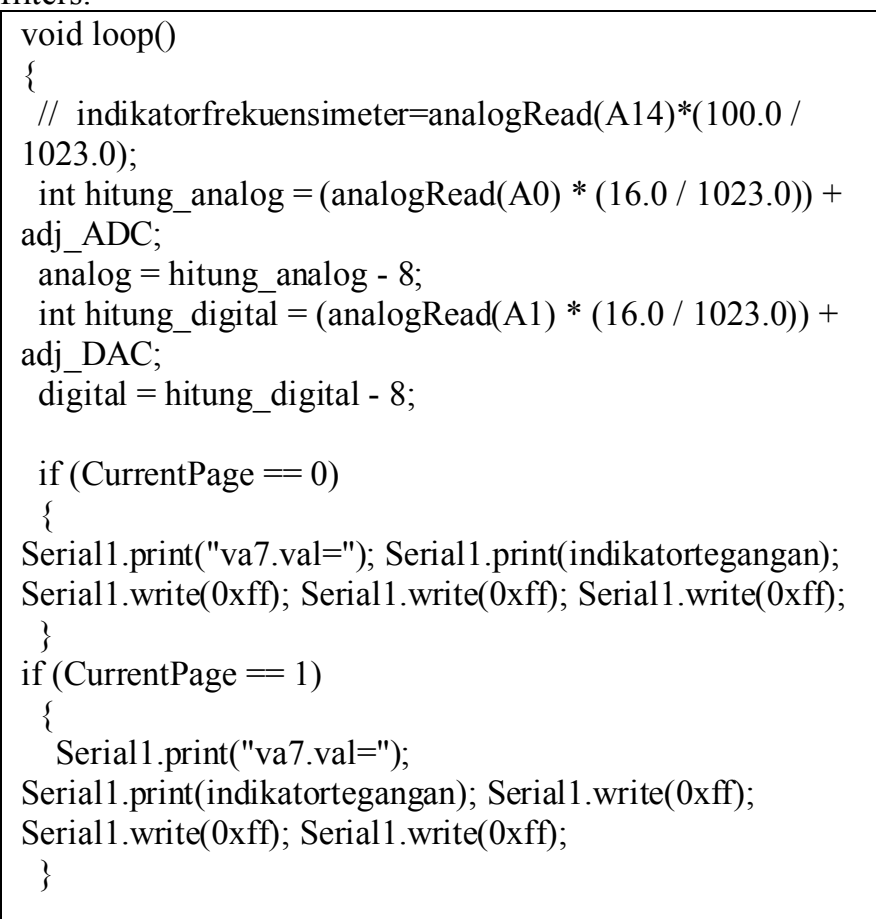

\section{F. Listing Program for Display}

Program for entering the TFT LCD library nextion to connect with Arduino. The above program also contains variables for the name of the initialization char nextion and initialization button which will be sent to Arduino.
\#include $<$ Nextion.h $>$
int analog, digital, dopler;
int CurrentPage ;
NexPage page $0=$ NexPage $(0,0$, "page0");
NexPage page $1=$ NexPage $(1,0$, "page $1 ")$;
NexPage page 2 - NexPage $(2,0$, "page2");
NexPage page $3=$ NexPage $(3,0$, "page3");
NexPage page4 = NexPage(4, 0, "page4");
NexPage page5 = NexPage(5, 0, "page5");
NexButton $b 0=$ NexButton(6, 17, "b0");
NexButton b1 = NexButton(6, 18, "b1");
NexButton b2 = NexButton(6, 20, "b2");
NexButton b3 = NexButton(6, 21, "b3");
NexButton b4 = NexButton(6, 23, "b4");
NexButton b5 = NexButton(6, 24, "b5");
NexButton b6 = NexButton(6, 26, "b6");
NexButton b7 = NexButton(6, 27, "b7");
NexButton b8 = NexButton(6, 29, "b8");
NexButton b9 = NexButton(6, 30, "b9");

NexButton b10 = NexButton(6, 32, "b10");

NexButton b11 = NexButton(6, 33, "b11");

NexButton b12 = NexButton(6, 36, "b12");

char buffer[1000] $=\{0\}$;

NexTouch *nex_listen_list[] =

\{

\&page 0, \&page1, \&page2, \&page3, \&page4, \&page5,

\&page6,

\&b0, \&b1, \&b2, \&b3, \&b4, \&b5, \&b6, \&b7, \&b8, \&b9,

$\& \mathrm{~b} 10, \& \mathrm{~b} 11, \& \mathrm{~b} 12$,

NULL

;

Serial1.print("n2.val="); Serial1.print(adj_DAC);

Serial1.write(0xff); Serial1.write(0xff); Serial1.write(0xff);

Serial1.print("n3.val="); Serial1.print(adj ADC);

\section{G. Listing Program for digital filter}

The program functions as a digital filter with a cuttoff frequency $=20-40$, order $=2$, bandpass filter, iir, chebysevtype 1 with a sampling frequency $=200 \mathrm{~Hz}$.

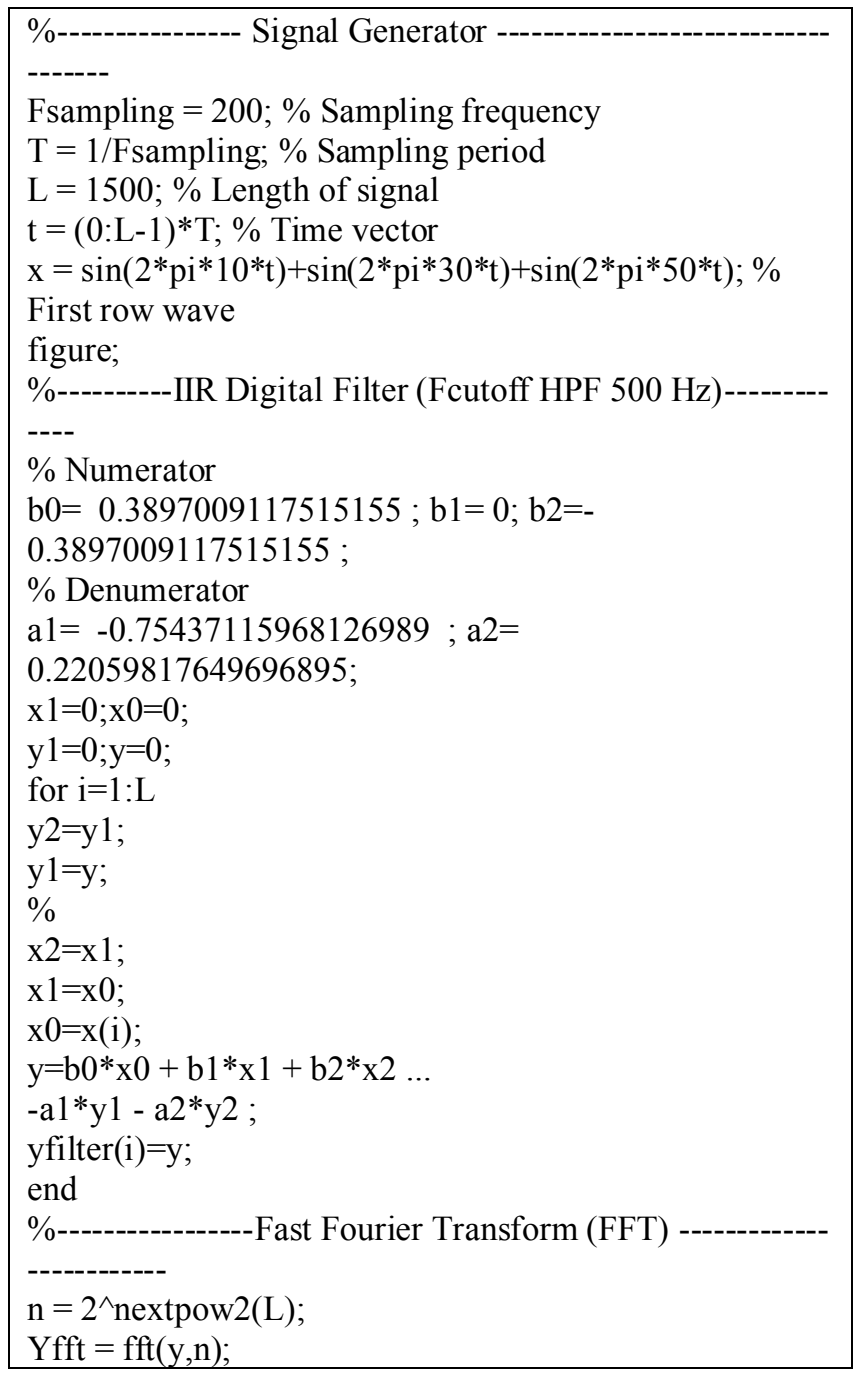




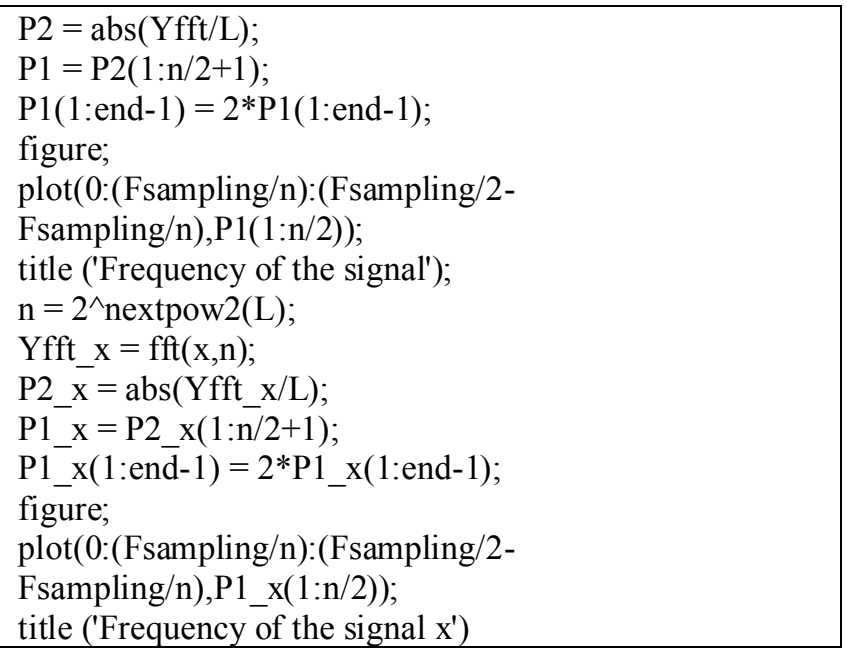

H. The Measurement Result for Respondent

TABLE I. RESULTS OF BPM MEASUREMENT IN RESPONDENT USING ANALOG FILTER

$\begin{array}{lccc}\text { Device } & \text { Mean } & \text { SD } & \text { Ua } \\ & (\text { BPM }) & (\text { BPM }) & \end{array}$

\begin{tabular}{cccc}
\hline $\begin{array}{c}\text { Module Device } \\
\text { (Analog Filter ) }\end{array}$ & 79 & 5.05 & 2.06 \\
\hline $\begin{array}{c}\text { Comparison } \\
\text { (pulse Oxymetri) }\end{array}$ & 81 & 0,89 & 0,36 \\
\hline
\end{tabular}

In (TABLE I.), the results of a comparison of the BPM ON ANALOGUE FILTER between the module and the matching device by doing ONE trial and each experiment is taken 6 measurement data, then the average results and standard deviation of BPM will be obtained. The average BPM value is 79. The standard deviation of the BPM is 5,05 .

TABLE II. RESULTS OF BPM MEASUREMENT IN RESPONDENT USING DIGITAL FILTER

$\begin{array}{cccc}\text { Device } & \begin{array}{c}\text { Mean } \\ \text { (BPM) }\end{array} & \text { SD } & \text { (BPM) }\end{array}$

\begin{tabular}{cccc}
\hline $\begin{array}{c}\text { Module Device } \\
\text { (Digital Filter ) }\end{array}$ & 91,5 & 1,32 & 0,54 \\
\hline $\begin{array}{c}\text { Comparison } \\
\text { (pulse Oxymetri) }\end{array}$ & 81 & 0,89 & 0,36 \\
\hline
\end{tabular}

In (TABLE II.), the results of a comparison of BPM ON DIGITAL FILTERS between modules and a matching device by doing ONE trial and each experiment is taken 6 measurement data, then the average results and standard deviation of BPM will be obtained. The average BPM value is 91.5 The standard deviation of BPM is 1,32 .

\section{DISCUSSION}

Based on the above module results, fetal heart rate signals are obtained using a piezoelectric transducer equipped with an amplifier and filter. Analog filter uses bandpass filter frequency of $20-40 \mathrm{~Hz}$, the results of filter measurements can be seen in fig. 9 and digital filters use type Chebyshev type 1 filter with the same frequency of $20-40 \mathrm{~Hz}$ frequency, the frequency outside cutoff frequency will be pressed, seen in fig.10 and fig.11. from the results of the analog filter output and digital filter, when the tool is tested on respondents it appears that the bpm value using an analog filter there is a standard deviation of 5.05 and the bpm value using a digital filter there is a standard deviation at 1.32. The use of an appropriate filter is very important, using a cutoff frequency of $20 \mathrm{~Hz}-40 \mathrm{~Hz}$ following the frequency of the fetal heart rate [20]. In the use of filters that need to be improved is to try other types of digital filters with an add orde of emphasis.

\section{CONCLUSION}

The purpose of this study is to make a fetal heart rate monitor displayed on a TFT LCD. In this study, the author uses a digital filter IIR Method Chebyshev type 1 and an analog bandpass filter with a cutoff frequency of $20-40 \mathrm{~Hz}$ on the Arduino 2560 embedded system and displays fetal heart rate graph and BPM value. Accu is used as a supplier of power (portable). This study was conducted once as many as 6 data retrieval data and compared the bpm value of the module with the bpm value of pulse oxymetry. This research has found that the use of analog filters is better than digital filters because of the orde of digital filters that only use the second order. From these results, a portable fetal heart rate meter can be made and displayed on the TFT LCD so that it will facilitate the user when it is a checkup. For development that should be done is to try other types of digital filters with additional emphasis, and make the transducer into a wireless system.

\section{REFERENCESS}

[1] E. L. Achadi, "Kematian Maternal dan Neonatal di Indonesia," Rakerkernas 2019, pp. 1-47, 2019.

[2] S. S. Sarimawar Djaja, "Penyebab Kematian Bayi Baru Lahir (Neonatal) dan Sistem Pelayanan Kesehatan Yang berkaitan Di Indonesia SKRT 2001, Puslitbang Ekonomi Kesehatan dan Badan Litbangkes," Bul.Penel.Kesehatan, vol. vol.31.No3, pp. 155-165, 2003.

[3] A. Saptanto and H. D. Anggraheny, "Faktor Risiko yang Mempengaruhi Kematian Bayi Asfiksi beberapa saat 
setelah lahir yang terjadi secara spontan dan teratur . Asfiksia terjadi karena sesuai dan besarnya di ukur dengan menggunakan rumus solven, dihasilkan jumlah sampel perawatan neonatal d," pp. 1-12, 2012.

[4] H. Y. Chen, S. P. Chauhan, C. V. Ananth, A. M. Vintzileos, and A. Z. Abuhamad, "Electronic fetal heart rate monitoring and its relationship to neonatal and infant mortality in the United States," Am. J. Obstet. Gynecol., vol. 204, no. 6, pp. 491.e1-491.e10, 2011, DOI: $10.1016 /$ j.ajog.2011.04.024.

[5] N. P. Meisuri et al., "Faktor Determinan yang Mempengaruhi Kejadian Kematian Perinatal Determinant Factors Affecting Perinatal Mortality Occurrence," vol. 7, pp. 121-127, 2018.

[6] The American College of Obstetricians and Gynecologists, "Special tests for monitoring fetal health.," Faq, 2018.

[7] I. S. Faradisa, T. A. Sardjono, and M. H. Purnomo, "TEKNOLOGI PEMANTAUAN KESEJAHTERAAN JANIN," pp. 1-6, 2017.

[8] J. W. Wladimiroff, P. A. Stewart, and R. P. L. Vosters, "Fetal cardiac structure and function as studied by ultrasound," Clin. Cardiol., vol. 7, no. 5, pp. 239-253, 1984, DOI: $10.1002 /$ clc.4960070501.

[9] E. W. Abdulhay, R. J. Oweis, A. M. Alhaddad, F. N. Sublaban, M. A. Radwan, and H. M. Almasaeed, "Review Article: Non-Invasive Fetal Heart Rate Monitoring Techniques," Biomed. Sci. Eng., vol. 2, no. 3, pp. 53-67, 2014, DOI: 10.12691/bse-2-3-2.

[10] J. C. P. Ferreira et al., "The evolution of fetal presentation during pregnancy: A retrospective, descriptive cross-sectional study," Acta Obstet. Gynecol. Scand., vol. 94, no. 6, pp. 660-663, 2015, DOI: 10.1111/aogs.12626.

[11] M. A. Hasan, M. B. I. Reaz, M. I. Ibrahimy, M. S. Hussain, and J. Uddin, "Detection and processing techniques of FECG signal for fetal monitoring," Biol. Proceed. Online, vol. 11, no. 1, pp. 263-295, 2009, DOI: $10.1007 / \mathrm{s} 12575-009-9006-\mathrm{z}$.

[12] N. Chabibah, "Perbedaan frekuensi denyut jantung janin berdasarkan paritas dan usia kehamilan," vol. 6 , no. 1, pp. 195-198, 2017.

[13] N. Amira et al., "Home based fetal heart rate monitor Home Based Fetal Heart Rate Monitor," no. January 2017.

[14] Nuryati, "Rancang bangun alat pendeteksi dan penghitung detak jantung dengan asas doppler skripsi," 2010.

[15] P. Hamelmann et al., "Doppler Ultrasound Technology for Fetal Heart Rate Monitoring: A Review," IEEE Trans. Ultrason. Ferroelectr. Freq. Control, vol. 67, no. 2, pp. 226-238, 2020, DOI: 10.1109/TUFFC.2019.2943626.

[16] “Doppler portable," vol. 7, no. 2, pp. 644-649, 2012.

[17] K. Dan and S. Intelijen, "Teknologi Informasi Dan
Komunikasi ( Tik ) Untuk Ketahanan Nasional," Komput. Dan Sist. Intelijen, vol. 7, no. 2302-3740, pp. 311-316, 2012, [Online]. Available: http://penelitian.gunadarma.ac.id/kommit.

[18] M. R. Makruf, "Perancangan filter digital pada fetal doppler," vol. 8, no. 1, pp. 705-710, 2013.

[19] R. Nurmala, Implementasi Dan Analisis Fetal Doppler Untuk Mendeteksi Detak Jantung Janin Dengan Pengolahan Sinyal Digital. 2015.

[20] B. Adiguna, A. Rizal, and U. B. Hanafi, "Aplikasi Pengukuran Denyut Jantung Janin Berbasis Ultrasonic Doppler Fetus Monitor," 2007.

[21] Affandy, "NON STRESS TEST TAMPIL PC," pp. 18, 2016.

[22] W. Hooker, "Properties Ceramics of PZT-Based Piezoelectric and $250^{\circ}$ C," no. September 1998, 2019.

[23] R. E. Saputro, "IIR Filter." 2015.

[24] V. Chourasia and A. Mittra, "Passive Acoustic Signal Acquisition System for Non- Invasive Fetal Heart Sound Monitoring Applications .," vol. 5, no. 1, pp. 18,2008

[25] Arduino, "Arduino Mega 2560 Datasheet," 2005.

[26] Nextion, "NX8048T050," Nextion, vol. 050, 2017. 